\title{
SOME PRODUCTIVE AND PHYSIOLOGICAL RESPONSES OF LACTATING EGYPTIAN BUFFALOES AS AFFECTED BY DIETARY SUPPLEMENTATION OF PROTECTED FAT
}

\author{
A.K.I. Abd-El Moty, E.B. Soliman, S.T.M. Fahmy and E.M. Ibrahim \\ Animal Production Department, Faculty of Agriculture, El-Minia University, El-Minia, Egypt
}

\section{SUMMARY}

Six multiparous lactating Egyptian buffaloes in their second and fourth season of lactation after their peak of milk production were used in two complete balanced period's changeover design experiment during January to March. Three experimental rations (T1, T2 and T3) were fed in amounts to meet 100, 110 and $115 \%$ of their AFRC (1993) metabolizable energy (ME) requirements. The protected fat (calcium salts of palm oil fatty acids) was added daily and mixed with the concentrate mixture in T2 and T3. All concentrate mixtures were iso-nitrogenous. Sugarcane bagasse was offered ad libitum as a roughage source. Protected fat supplementation increased $(P<0.05)$ milk yield, $7 \%$ FCM, milk fat yield and total dry matter intake. The rectal temperature decreased $(P<0.05)$ at 8.00 am and 2.00 pm for buffaloes fed protected fat supplemented rations (T2 and T3) compared with those fed the control ration (T1). However, fat supplementation had no effect on respiration rate at 8.00 am however, decreased $(P<0.05)$ at $2.00 \mathrm{pm}$ for buffaloes fed T2 and T3 compared with those fed T1. Blood hemoglobin increased $(P<0.05)$ for buffaloes fed on T2 and T3 when compared with those fed $T 1$ ration. Protected fat supplementation led to an increase $(P<0.05)$ in packed cell volume, red blood cell counts, white blood cell counts and corpuscular hemoglobin and corpuscular volume. However, the values of corpuscular hemoglobin concentration did not change due to fat supplementation. The concentrations of plasma glucose, total protein, albumin and globulin increased $(P<0.05)$ for buffaloes fed T2 and T3 compared with those fed T1. Also, concentrations of plasma total lipids, cholesterol and triglycerides were higher $(P<0.05)$ for buffaloes fed $T 2$ and T3 than those fed T1. Also, the concentrations of triiodothyronine and thyroxin were higher $(P<0.05)$ for buffaloes fed $T 2$ and T3 than those fed T1. This study indicated that protected fat supplementation in lactating buffaloes can be improved some of their productive and physiological responses, indicating that the efficient metabolic activities of these animals were enhanced.

Keywords: Productive and physiological responses, lactating buffaloes, supplemental protected fat

\section{INTRODUCTION}

Buffalo's milk contributes about $73 \%$ of the total milk production in Egypt (AbouHussein et al., 2003). Calcium salts of palm oil fatty acids permit the total dietary fatty acid digestibility to be high compared to other fat supplements (Block et al., 2005). Thus, supplementing the ration of lactating cows with calcium salts of palm oil fatty acid can improve the milk production as well as milk quality (Purushothaman et al., 2008). Buffalo's productivity is affected by many factors. Some of these are nutritional, genetical, hygienic, physiological, etc. Physiological reactions such as body temperature and respiration rate in response to fat supplementation were studied by many investigators (Soliman et al., 2001; Moallem et al., 2010; Wang et al., 2010; Zhang et al., 2011). Moreover, utilization of supplemental fat in cow rations has been described to positively or adversely affect hematological parameters (Rajora et al., 1997; Omer, 1999; and Awad, 2001), and blood metabolites (Marreck, 1996; El-Shewy, 1997; Bremmer et al., 1998; and Petit et al., 2004).
The objective of this study was to determine the effect of dietary protected fat (calcium salts of palm oil fatty acids) supplementation on some productive performances and physiological responses such as thermal responses, hematological characteristics as well as some blood metabolites and hormones levels of lactating Egyptian buffaloes.

\section{MATERIAL AND METHODS}

\section{Animals and experimental design:}

The present study was carried out at the farm of Animal Production Department, Faculty of Agriculture, El-Minia University. Six lactating Egyptian buffaloes of 561.0 \pm 33.0 $\mathrm{kg}$ body weight in second to fourth parity after the peak of milk production were used during January to March in a two complete balanced periods changeover experimental design (Gill and Magee, 1976). The experiment consisted of two periods. The animals were fed the tested dietary treatments for 28 days in each period (21 days for adaptation and 7 days for milk and blood samples collection). At the end of the 
first experimental period, the buffaloes were reassigned to the experimental diets for another 28 days period (the second experimental period). Along the experiment, each animal received two different dietary treatments and each diet was tested on four animals. Three experimental rations (T1, T2 and $\mathrm{T} 3$ ) were formulated to meet 100,110 and $115 \%$ of the buffaloes metabolizable energy requirements for maintenance and production calculated according to AFRC (1993) recommendations for dairy cattle. The control concentrate mixture in the first treatment (T1) contained $43.25 \%$ uncorticated cotton seed meal, $29.5 \%$ wheat bran, $11 \%$ molasses, $8.75 \%$ yellow corn, $3.75 \%$ rice bran, $2.5 \%$ calcium carbonate and $1.25 \%$ sodium chloride. Protected fat (calcium salts of palm oil fatty acids, Megalac $®$ ) was added daily to the concentrate mixture of T2 and T3. To achieve the 10 and $15 \%$ of the metabolizable energy requirements, the calcium salts of palm fatty acids represented 2.00 and $3.06 \%$ of the whole ration. The dietary treatments contain 11.23, 12.35 and 12.92 $\mathrm{MJ} \mathrm{ME} / \mathrm{kg} \mathrm{DM}$ for T1, T2 and T3, respectively. All concentrate mixtures were iso-nitrogenous and provide $172.5 \mathrm{~g}$ crude protein/kg DM (91.44 g metabolizable protein $/ \mathrm{kg} \mathrm{DM}$ ), according to the tabulated values for each ingredient (AFRC, 1993). Sugarcane bagasse was offered ad libitum as a roughage source. During the experimental periods, a commercial mineral mixture was mixed with the concentrate mixture $(1 \mathrm{~kg} / \mathrm{ton})$. In addition, vitamins $\mathrm{A}, \mathrm{D} 3, \mathrm{E}$ and $\mathrm{C}$ requirements were injected biweekly according to the NRC requirements (NRC, 2001). Animals were housed and fed in stables for individually. Fresh water was available along the experiment. Buffaloes were subjected to the routinely veterinary vaccination and inspection system.

\section{Milk sampling and measurements:}

Milk yield per each animal was recorded daily and milk samples $(10 \mathrm{ml} / \mathrm{kg}$ milk produced) from morning and afternoon milking were collected on days 24 and 27 of each period. Milk fat was measured by Gerber units (British Standard Institution, 1962). Total dry matter intake (TDMI, $\mathrm{kg} / \mathrm{h} / \mathrm{d}$ ) was calculated.

At the last week of each experimental period, thermal responses (rectal temperature, $\left(\mathrm{RT}{ }^{\circ} \mathrm{C}\right.$ ) and respiration rate, (RR, r.p.m) of each experimental lactating buffalo were recorded twice a day at 8.00 am and $2.00 \mathrm{pm}$ on days 24 and 27 of each period. Rectal temperature was recorded using clinical mercury thermometer inserted into the rectum for two minutes. Respiration rate was determined by counting the flank's movements per minute. Ambient temperature $\left(\mathrm{AT},{ }^{\circ} \mathrm{C}\right)$ and relative humidity ( $\mathrm{RH}, \%)$ were recorded at time of RT and RR measurements. Ambient temperature was measured using a thermometer hanged at a level of about two meters above the floor and the $\mathrm{RH}$ was recorded using a psychrometer. The averages of AT and RH during the experimental periods were $14.21^{\circ} \mathrm{C}, 39.56 \%$ at 8.00 am and $24.5^{\circ} \mathrm{C}$, $30.75 \%$ at $2.00 \mathrm{pm}$, respectively.

\section{Blood sampling and measurements:}

At the end of each period, heparinized blood samples were collected from the jugular vein of each animal at 8.00 am before feeding or watering. Whole blood samples were analyzed after collection for hemoglobin $(\mathrm{Hb}$, $\mathrm{gm} / \mathrm{dl})$, packed cell volume (PCV, \%), red blood cell counts (RBCs, x10 $1 \mathrm{~mm}^{3}$ ) and white blood cell counts (WBCs, $\times 10^{3} / \mathrm{mm}^{3}$ ). $\mathrm{The} \mathrm{Hb}$ concentration was determined by Shali's method. The PCV was determined using microhematocrite tubes with a microhematocrite centrifuge at 12000 r.p.m for three minutes. The RBCs and WBCs were counted using the light microscope. Mean corpuscular hemoglobin concentration [MCHC $=(\mathrm{Hb}$ in $\mathrm{gm} / \mathrm{dl}) / \mathrm{PCV} \%) \times 100)]$, mean corpuscular volume $[\mathrm{MCV}=(\mathrm{PCV}$ in a liter $) /$ RBCs in $\left.\mathrm{ml} / \mathrm{mm}^{3}\right)$ ] and mean corpuscular hemoglobin $[\mathrm{MCH}=(\mathrm{Hb}$ in gm/liter blood $) /$ $\left(\mathrm{RBCs}\right.$ in $\left.\mathrm{ml} / \mathrm{mm}^{3}\right)$ ] were calculated using the formulas proposed by Schalm (1965).

Plasma samples were collected by centrifugation of heparinized blood samples at 3000 r.p.m for 10 minutes. Blood plasma was kept frozen at $-20{ }^{\circ} \mathrm{C}$ for later analysis. Plasma triiodothyronine and thyroxin concentrations were determined by a direct solid-phase $\mathrm{I}^{125}$ radioimmunoassay techniques using (coat-Acount $\mathrm{TKT}_{3}$ and $\mathrm{TKT}_{4}$ ) RIA Kits purchased from Diagnostic Products Corporation (DPC, Los Angeles, CA, 90045-5597, USA). Thyroxin/triiodothyronine ratio was calculated. Plasma glucose $(\mathrm{mg} / \mathrm{dl})$, cholesterol $(\mathrm{mg} / \mathrm{dl})$ and triglycerides $(\mathrm{mg} / \mathrm{dl})$ were determined using Bio-Merieux Kits (marcy-1, Etolie Charbnnieres-Les-Bains, France). Plasma total protein $(\mathrm{g} / \mathrm{dl})$, albumin $(\mathrm{g} / \mathrm{dl})$ and total lipids $(\mathrm{mg} / \mathrm{dl})$ were determined using Bio-Analytics Kits (USA), however plasma globulin concentrations were calculated by difference between total protein and albumin concentrations.

\section{Statistical analysis:}

Duncan's multiple rang test (Duncan, 1955) was used to determine the significance among treatment means using the GLM procedure of SAS (1990) for a completely two period changeover design (Gill and Magee, 1976) according to the linear model:

$$
\mathrm{Y}_{\mathrm{ijk}}=\mu+\alpha_{\mathrm{i}}+\beta_{\mathrm{j}}+\mathrm{T}_{\mathrm{k}}+\mathrm{E}_{\mathrm{ijk}}
$$


Where,

$\mu=$ The overall mean,

$\alpha=$ The random effect of buffaloes ( $\mathrm{i}=1$, ....6),

$\beta=$ The fixed effect of experimental periods $j$ $=1,2$ ),

$\mathrm{T}=$ The fixed effect of dietary treatments $(\mathrm{k}=$ $1, . .3)$ and

$\mathrm{E}=$ The experimental error $\left(\mathrm{O}, \delta^{2}\right)$.

\section{RESULTS}

\section{Some productive performances:}

The results of milk yield, $7 \%$ FCM, milk fat yield and total dry matter intake are presented in Table (1). Values of milk yield were greater $(\mathrm{P}<0.05)$ for buffaloes of $\mathrm{T} 2$ and T3 than those of $\mathrm{T} 1$, by 18.9 and $35.8 \%$, respectively. Also, milk yield increased $(\mathrm{P}<0.05)$ by $14.2 \%$ in $\mathrm{T} 3$ group compared with T2. The yields of 7\% FCM were higher $(\mathrm{P}<0.05)$ for buffaloes of $\mathrm{T} 2$ and $\mathrm{T} 3$ than those of $\mathrm{T} 1$. The increases in $7 \% \mathrm{FCM}$ were 25.78 and $52.75 \%$ in $\mathrm{T} 2$ and $\mathrm{T} 3$ compared with $\mathrm{T} 1$. Milk fat yield was higher $(\mathrm{P}<0.05)$ for buffaloes fed $\mathrm{T} 2$ and $\mathrm{T} 3$ than those fed ration of T1. These increases in milk fat yield were calculated to be 28.1 and $58.6 \% \mathrm{~T} 2$ and $\mathrm{T} 3$ more than control one. The values of total dry matter intake (TDMI) were increased $(\mathrm{P}<0.05)$ by 7.8 and $17.8 \%$ for buffaloes fed rations $\mathrm{T} 2$ and $\mathrm{T} 3$ when they compared with those fed T1, respectively. The calculated efficiency of FCM production per kg TDMI was higher $(\mathrm{P}<0.05)$ by 18.0 and $30.0 \%$ for buffaloes fed $\mathrm{T} 2$ and $\mathrm{T} 3$ than those fed the control ration of $\mathrm{T} 1$.

\section{Thermal responses:}

Data presented in Table (2), showed the effect of protected fat supplementation on rectal temperature $\left(\mathrm{RT},{ }^{\circ} \mathrm{C}\right)$ of lactating buffaloes. These results revealed that RT decreased $(\mathrm{P}<0.05)$ by 1.03 and $1.43 \%$ at 8.00 am and by 1.12 and $1.67 \%$ at $2.00 \mathrm{pm}$ when buffaloes were fed $\mathrm{T} 2$ and $\mathrm{T} 3$ as compared with $\mathrm{T} 1$. There was no significant difference in RT among buffaloes fed rations T2 and T3. Data of respiration rate (RR, r.p.m) showed that there was no significant difference among the three experimental rations at $8.00 \mathrm{am}$. However, there was a significant $(\mathrm{P}<0.05)$ decrease in the values of RR at $2 \mathrm{pm}$ by 15.12 and $18.91 \%$ for buffaloes fed rations T2 and T3 comparing to control ration (T1). No significant difference was detected between buffaloes fed rations $\mathrm{T} 2$ and $\mathrm{T} 3$.

\section{Hematological parameters:}

Data in Table (3) indicated that the values of hemoglobin $(\mathrm{Hb})$ increased $(\mathrm{P}<0.05)$ by 13.00 and $22.54 \%$ for buffaloes fed rations of $\mathrm{T} 2$ and $\mathrm{T} 3$ compared with control ration group
(T1). However, Hb values increased by $8.44 \%$ when T3 was compared with T2, but the differences were not significant. Also, the results indicated that the percentage of $\mathrm{PCV}$ increased $(\mathrm{P}<0.05)$ by 12.70 and $20.63 \%$ for buffaloes fed rations $\mathrm{T} 2$ and $\mathrm{T} 3$, respectively when compared with control ration. However, there was no significant difference in PCV percentage among buffaloes fed rations $\mathrm{T} 2$ and T3. As shown in Table (3), blood cell count's (RBC's and WBC's) increased $(\mathrm{P}<0.05)$ by 5.34 and $9.96 \%$ for RBC's and 3.34 and 6.20 $\%$ for WBC's due to feeding $\mathrm{T} 2$ and $\mathrm{T} 3$, respectively in comparison with $\mathrm{T} 1$. The results revealed that the calculated hematological parameters such as corpuscular hemoglobin, corpuscular volume increased $(\mathrm{P}<0.05)$ when $\mathrm{T} 2$ or $\mathrm{T} 3$ were fed in comparison with $\mathrm{T} 1$, by 7.24 and $8.68 \%$ for $\mathrm{MCH} ; 6.66$ and $9.69 \%$ for MCV, respectively. However, the values of corpuscular hemoglobin concentration were not significantly affected as a result of protected fat supplementation.

\section{Plasma metabolites:}

Buffaloes fed T2 and T3 had higher $(\mathrm{P}<0.05)$ values of plasma glucose than those fed T1 ration by 15.97 and $26.05 \%$, respectively more than $\mathrm{T} 1$ group. Plasma glucose concentrations also increased $(\mathrm{P}<0.05)$ by $8.70 \%$ for buffaloes fed T3 compared to T2 (Table 4). Also, the results indicated that the averages of total protein concentrations increased $(\mathrm{P}<0.05)$ by 4.94 and $9.04 \%$ for buffaloes fed $\mathrm{T} 2$ and $\mathrm{T} 3$, respectively compared with T1. There was no significant difference in plasma total protein among buffaloes fed ration $\mathrm{T} 2$ and $\mathrm{T} 3$. Also data showed that plasma albumin was greater $(\mathrm{P}<0.05)$ for buffaloes fed rations $\mathrm{T} 2$ and $\mathrm{T} 3$ than those fed ration $\mathrm{T} 1$ by 7.89 and $8.68 \%$ for buffaloes fed $\mathrm{T} 2$ and $\mathrm{T} 3$, respectively relative to $\mathrm{T} 1$. No significant difference in plasma albumin concentration was observed among buffaloes fed rations T2 and T3. Data of plasma globulin showed that there was significant $(\mathrm{P}<0.05)$ increases by 9.78 and $8.1 \%$ for buffaloes fed $\mathrm{T} 3$ when compared to those fed $\mathrm{T} 1$ and $\mathrm{T} 2$, respectively. Ratios of Albumin/Globulin were not significantly different among the three rations. Data in Table (4) revealed that protected fat supplementation had positive $(\mathrm{P}<0.05)$ effect on plasma total lipids. The determined values were higher by 17.75 and $28.99 \%$ for buffaloes fed $\mathrm{T} 2$ and $\mathrm{T} 3$, respectively compared to control ration (T1). Difference among buffaloes fed T2 and those fed T3 were significant $(\mathrm{P}<0.05)$. The superiority was 9.55 $\%$ in favor buffaloes fed T3. As shown in 
Table (4), the differences in plasma cholesterol values were significantly $(\mathrm{P}<0.05)$ affected by the experimental fat supplementation. The buffaloes fed supplemented fat ration had higher $(\mathrm{P}<0.05)$ values for plasma cholesterol. The increment was 17.16 and $40.30 \%$ for T2 and $\mathrm{T} 3$, respectively compared to the control ration. The concentrations of triglycerides were higher $(\mathrm{P}<0.05)$ for buffaloes fed $\mathrm{T} 2$ and $\mathrm{T} 3$ than those fed the control ration. These increases were 42.57 and $101.12 \%$ when treatments T2 and T3 were compared with T1. At the same time, there was a significant $(\mathrm{P}<0.05)$ increase in triglycerides values for buffaloes fed T3 compared with those fed T2. The increment represents $24.31 \%$ for T3 above $\mathrm{T} 2$.

\section{Plasma hormones:}

Results indicated that $\mathrm{T} 3$ treatment increased $(\mathrm{P}<0.05)$ plasma triiodothyronine level by 20.66 and $14.06 \%$ more than $\mathrm{T} 1$ and $\mathrm{T} 2$ respectively, (Table 4 ). The results revealed that, addition of fat to lactating buffaloes as $10 \%$ (T2) and $15 \%$ (T3) of their metabolizable energy requirements increased their plasma thyroxin level. This increase was 26.63 and $47.84 \%$ for $\mathrm{T} 2$ and $\mathrm{T} 3$, respectively in comparison with T1. Also, thyroxin level was greater $(\mathrm{P}<0.05)$ by $16.75 \%$ upon feeding treatment T3 compared with T2. Data in Table (4) also showed that the calculated thyroxin/triiodothyronine ratio increased $(\mathrm{P}<0.05)$ by 19.68 and $22.53 \%$ for buffaloes fed T2 and T3 rations when compared with the control ration. Buffaloes fed T3 showed higher ratio $(2.38 \%)$ than those fed $\mathrm{T} 2$, but the variance did not achieve a significant effect.

\section{DISCUSSION}

The improvement in milk yield by 18.9 and $35.8 \%$ for buffaloes fed T2 and T3 compared to control ration is in agreement with the results of Purushothaman et al. (2008). They indicated that supplementing the ration of lactating cows with calcium salts of palm oil fatty acids caused a substantial improvement in the milk yield. They reported that $4 \%$ bypass fat supplementation showed a significant increase in milk yield by $19.0 \%$ as compared to the control. In the present study, the increases in $7 \%$ FCM were calculated to be 25.78 and $52.75 \%$ and the milk fat yield also increased by 28.1 and $58.6 \%$ for buffaloes fed calcium salts of palm oil fatty acids supplemented rations. These results are in agreement with Petit et al. (2004) who stated that milk yield, FCM and milk fat yield increased by 27.0, 25.1 and $23.5 \%$, respectively for lactating cows fed $4.6 \%$ calcium salts of palm oil compared with the control diet. It is interesting to notice that the
TDMI increment as a result of fat supplementation. These results are in agreement with the study of Chan et al. (1997) and Basiony (1998). They reported that DMI increased by 13.6 and $16.35 \%$ for cows and buffalo calves fed $2.5 \%$ prilled fatty acids, respectively compared with those fed the control ration. Thus, the efficiency of FCM per $\mathrm{kg}$ TDMI was also improved for lactating buffaloes fed calcium salts of palm oil fatty acids in the present study.

The significant reduction observed in $\mathrm{RT}$ at $8.00 \mathrm{am}$ and $2.00 \mathrm{pm}$ for buffaloes fed protected fat supplemented rations could be understood as significantly lower heat production. In other words, it reduced significantly less heat increment and heat of fermentation. This means more efficient utilization of dietary digestible and metabolizable energy. In the same way, greater portion of dietary energy is used for productive aspects. Accordingly the milk yield, 7\% FCM and milk fat yield were enhanced in the present study. As reported by Zhang et al. (2011), $1.5 \%$ dietary fat supplementation in earlylactating cows decreased RT and RR, discussing that fat has a low heat increment associated with feeding, and is also accompanied by a high energy density, thus it is utilized with high efficiency. Although fat supplementation of calcium salts of fatty acids ( $1.5 \%$ of diet) in high-yielding dairy cows was effective in reducing metabolic heat production, increasing the energy density, and thus increased metabolic efficiency to enhance milk production, however, the changes were not reflected in RT and RR (Moallem et al., 2010). Rectal temperatures at $1400 \mathrm{~h}$ decreased accompanied with fat supplementation, demonstrating a remarkable amount of metabolic heat that is saved by energetically replacing fermentable carbohydrates with supplemental fat (Wang et al., 2010).

It is quiet accepted that the RT is affected by the environmental temperature. The temperature of the stable was $14.21^{\circ} \mathrm{C}$ at 8 am, while it was $24.5^{\circ} \mathrm{C}$ at $2.00 \mathrm{pm}$. Therefore, it is reasonably to find higher RT at $2.00 \mathrm{pm}$ than at 8 am. Discussing the RR data could not be done away from the RT results, where both of them are expression for the balance between the internal biological system and the animal surrounding environment. The respiration rate data express that animals fed protected fat supplemented rations are in more comfortable and relaxant state. Respiration is one of the ways that enable animals to get rid of the excessive heat. This fact was strictly clear when RR values recorded at $2.00 \mathrm{pm}$ were higher in comparison with the RR values at 8.00 am of this study. 
Blood $\mathrm{Hb}$ is responsible for cellular oxidation through $\mathrm{O}_{2}$ supply and washing out the un-required $\mathrm{CO}_{2}$. High $\mathrm{Hb}$ concentration in blood of protected fat fed buffaloes indicates greater supply of $\mathrm{O}_{2}$ that required for metabolic and synthetic processes, leading to greater milk and milk constituents yields (Vandeharr, 2005). Such increase in blood Hb was accompanied with significant higher values of $\mathrm{MCH}$ values. As a matter of fact, variation in $\mathrm{Hb}$ synthesis is reflected by increasing or decreasing in $\mathrm{MCH}$ values (Benjamin, 1978). The present results of PCV\% increased significantly in animals fed protected fat supplemented ration. These results are in agreement with those of Soliman et al. (2001) who reported that PCV\% increased for dairy cows fed fat-supplemented diets compared with control diet. The increment in WBC's in animals fed fat supplemented ration may express the better hygienic situations as high producing animals are more susceptible to microbial invasion than lower producing animals.

Fat supplementation may help in saving glucose from oxidation to be used in lactose synthesis (Vandeharr, 2005). Feeding Holstein cows rumen-protected fat $(50 \mathrm{~g} / \mathrm{kg} \mathrm{DM})$, showed greater milk and lactose yields associated with elevation in lipids and glucagon concentrations despite lower plasma glucose concentration, suggesting a glucosesparing effect allowing an enhanced lactose synthesis (Hammon et al., 2008). Other possible reasons were that supplemental fat would provide precursors for gluconeogenesis, thereby increasing blood glucose concentration, or that glycolysis of sugar was inhibited by supplemental dietary fat in order to improve their energy levels (Juchema et al., 2008). It should consider that bypass fats are hydrolyzed to their polyunsaturated fatty acids and glycerol, a precursor for glucose (Morsy, 2008). The response of increasing plasma glucose shown in the present study is in accordance with studies of Garcia et al. (1998), Petit et al. (2004), Harvatine and Allen (2005), Juchema et al. (2008) and Zhang et al. (2011). Petit et al. (2004) found a significant increase amounted in plasma glucose by $5.09 \%$ for cows fed $4.6 \%$ calcium salts of palm oil. In addition, cows fed calcium salts of fish and palm oil had greater concentrations of glucose which can be related to plasma insulin concentrations (Juchema et al., 2008), as plasma insulin concentration was decreased by $27 \%$ for cows fed calcium salts of unsaturated fatty acids (Harvatine and Allen, 2005). Another work on dairy cows showed no change in their plasma glucose due to fat supplementation (Christensen et al., 1996). In contrast, plasma glucose was slightly decreased for dairy cows fed diets containing $3 \%$ Ca salts of long chain fatty acids (Erickson et al., 1992).

A tendency to increase plasma total protein in the present study was also observed in dairy cows fed fat-supplemented rations (Soliman et al., 2001). Such trend was in accordance with milk protein content and ascertains the merit for improving milk production performance of animals according to increasing the dietary energy density (Fahmy et al., 2000). It should consider that plasma albumin is an important source of available amino acids that can support amino acids need when dietary supplies are limited (Moorby et al., 2002). Blood amino acids are used in several aspects such as in gluconeogenesis, synthesis of milk protein, synthesis of enzymes secreted via gastric juice and restoring cell deprive. Therefore, it's concentration in blood are the balance among these issues (Vandeharr, 2005).

Buffaloes fed protected fat supplemented rations showed higher plasma concentrations of total lipids, cholesterol and triglycerides. Similar response was observed in dairy cows due to dietary fat supplementation (Soliman et al., 2001). Fat supplementation, in addition to its effect to improve milk production, increased the ether extract $(\%)$ and its digestibility coefficients as a result to feeding $\mathrm{Ca}$ salts of palm oil fatty acids in lactating cows (Purushothaman et al., 2008). Accordingly, the elevated plasma total lipids concentration was accompanied with a significant increase in milk fat yield as pointed out in the present study. This increment in total lipid concentration exerted its effect on fat concentration of milk and the yield of milk fat in dairy cows (Fahmy et al., 2000). The present results are consistent with a study concluded that supplementation of Friesian bull's diet with 4 or $8 \%$ Ca soap of fatty acids increased plasma total lipids by 14 and $17 \%$ compared with those fed the control diet (Omer, 1999). Likewise, Petit et al. (2004) observed that cholesterol concentrations were significantly higher for cows fed $4.6 \%$ calcium salts of palm oil compared with those fed the control diet. Plasma non-esterified fatty acid and triglyceride concentrations were significantly increased in Holstein cows fed rumen-protected fat $(50 \mathrm{~g} / \mathrm{kg} \mathrm{DM})$, revealing an elevation in their lipid status (Hammon et al., 2008). As reported by Zhang et al. (2011), dietary fat supplementation induced significant increases in total triglycerides, total cholesterol and high density lipoprotein in early-lactating cows. However, addition of $\mathrm{Ca}$ salts of fatty acids at levels of 3 or $5 \%$ to the diets of lactating dairy goats in early lactation have 
limited effect on blood levels of cholesterol and triglycerides (Titi, 2011). Blood levels of total lipids, cholesterol and triglyceride reflected the in vivo metabolism of lipids, and strong lipid metabolism can release more energy to decrease the duration and magnitude of negative energy status. In the same way, Christensen et al. (1996) documented that utilization of fat in dairy cows diet is positively reflected in their plasma cholesterol, attributing such rises in plasma cholesterol to the greater demand for cholesterol in processes of lipid digestion, absorption, transport and synthesis in the mammary gland. In addition, the increase of cholesterol level is required for absorption and transport of long chain fatty acids. Contrary to above, plasma cholesterol level was not changed by dietary fat supplementation as $5 \%$ Ca soap of fatty acids (Sklan et al., 1994).

It is quiet known that thyroid gland through its hormonal secretions (thyroproteins) master the general body metabolism and energy metabolism in particular (Frandson, 1986). The relation between protected fat supplementation and thyroid hormone concentrations could be due to more absorbed nutrients available to be metabolized. Substrate accumulation may accelerate the metabolic rate that is controlled by thyroid hormones. Moreover, it is known that animals eat to cover their needs from energy and protein (Forbes, 2000). According to the animals genetic potential the high producing animals ate more, the digestibility and metabolizability processes working more efficient and faster as a result of greater concentration of thyroid hormones. That was the case in this study where triiodothyronine concentrations were increased. The increase in thyroxin concentrations due to fat supplementation is in agreement with Grum et al. (1996) and Soliman et al. (2001) who worked on dairy cows fed fat-supplemented diets.

The present study concluded that protected fat supplementation in Egyptian lactating buffaloes can be improved their physiological responses and milk production, indicating that the efficient metabolic activities of these animals were enhanced.

\section{REFERENCES}

Abou Hussein, E.R.M., E.A. Gihad, T.M. ElBedawy and M. H. Abdel-Gawad, 2003. Effect of dietary oilseed supplement on nutrient utilization, milk yield and composition of lactating buffaloes. Egyptian J. Anim. Prod.; 1: 27-42.

AFRC, 1993. Technical committee on responses to nutrients. Energy and protein requirements of ruminants. $\mathrm{CAB}$ international, Wallingford, Oxon, OX 10 8DE, U. K.

Awad, A.S.S, 2001. Performance of fattening bulls fed diets supplemented with protected fat. Ph.D. Thesis, Faculty of Agriculture, Cairo University, Giza, Egypt.

Basiony, A.K., 1998. Growth performance of post weaned buffalo calves fed fat supplemented rations. M.Sc. Thesis, Faculty of Agriculture, Cairo University, Giza, Egypt.

Benjamin, M.M., 1978. Outline of veterinary clinical pathology. $3^{\text {rd }}$ ed. Iowa State Univ. Press, Ames. Iowa, USA.

Block, E., W. Chalupa, E. Evans, T. Jenkins, P. Moate, D. Palmquist and C. Sniffen, 2005. Calcium salts yield highest digestibility. Feedstuffs; 77:1-8.

Bremmer, D.R., L.D. Ruppert, J.H. Clark and J.K. Drackley, 1998. Effects of chain length and unsaturation of fattty acids mixtures infused into the abomasum of lactating dairy cows. J. Dairy Sci.; 81: 176188.

British Standards Institution, 1962. British Standard methods for determination of milk fat, the Gerber method. Bullg, P. 962.

Chan, S.C., J.T. Hubber, C.B. Theurer, Z. Wu; K.H. Chen and J.M. Simas, 1997. Effect of fat supplementation and protein source on performance of dairy cows in hot environmental temperatures. J. Dairy Sci.; 75: (Suppl. 1): 175. (Abst.)

Christensen, R.A., T.R. Overton, J.H. Clark, J.K. Drackely, D.R. Nelsen and S.A. Blum, 1996. Effects of dietary fat with or without nicotinic acid on nutrient flow to the duodenum of dairy cows. J. Dairy Sci.; 79:1410-1424.

Duncan, D.B., 1955. Multiple range test and multiple F-test. Biometrics; 11: 1-42.

El-Shewy, A.A., 1997. Feeding lactation animals on some agricultural wastes and its effect on milk yield and composition. $\mathrm{Ph}$. D. Thesis, Faculty of Agriculture, Ain Shams University, Egypt.

Erickson, P.S., M.R. Murphy and J.H. Clark, 1992. Supplementation of dairy cows diets of calcium salts of long chain fatty acids and nicotinic acid in early lactation. $\mathrm{J}$. Dairy Sci.; 75:1078.

Fahmy, S.T.M., A.K.I. Abd El-Moty, E.B. Soliman and E.M. Ibrahim, 2000. Effects of fat supplementation on milk yield, milk composition and the feeding value of dairy cow's diet. Proc. of the $3^{\text {rd }}$ All Africa Conf. Anim. Agric. \& $11^{\text {th }}$ Conf. Egypt. Soc. of Anim. Prod. Alex. Egypt, 6-9 November, 143-148.

Forbes, J.M., 2000. Physiological and metabolic aspects of feed intake control in: Farm animal metabolism and nutrition. 
Chapter 15, P. 319. Ed. D’Mello, J.P.F. CABI publishing.

Frandson, R.D., 1986. Anatomy and physiology of farm animals. $4^{\text {th }}$ ed. Lea \& Febiger, Philadelphia.

Garcia, C.M., C.R. Staples, C.A. Risco, J.D. Savio and W.W. Thatcher, 1998. Protein degradability and calcium salts of longchain fatty acids in the diets of lactating dairy cows: Productive responses. J. Dairy Sci.; 81: 1374-1384.

Gill, J.L. and W.T. Magee, 1976. Balanced two-period changeover designs for several treatments. J. Anim. Sci.; 42: 775.

Grum, D.E., J.K. Drackley, L.R. Hansen and J. D. Cremin, JR., 1996. Production, digestion and hepatic lipid metabolism of dairy cows fed increased energy from fat or concentrate. J. Dairy Sci.; 79: 1836.

Hammon, H.M., C.C Metges, P. Junghans, F. Becker, O. Bellmann, F. Schneider, G. Nurnberg, P. Dubreuil and H. Lapierre, 2008. Metabolic changes and net portal flux in dairy cows fed a ration containing rumen-protected fat as compared to a control diet. J Dairy Sci.; 91:208-217.

Harvatine, K.J. and M.S. Allen, 2005. The effect of production level on feed intake, milk yield and endocrine responses to two fatty acid supplements in lactating cows. J. Dairy Sci.; 88:4018-4027.

Juchema, S.O., J.E.P. Santos, R.L.A. Cerri, R.C. Chebel, K.N. Galvao, R. Bruno, E.J. DePeters, T. Scott, W.W. Thatcher and D. Luchini, 2008. Effect of calcium salts of fish and palm oils on lactational performance of Holstein. Anim. Feed. Sci. Tech.; 140: 18-38.

Marreck, Y. A., 1996. Effect of feeding some by products on the performance of dairy buffaloes. Ph. D. Thesis, Faculty of Agriculture, Ain Shams University, Egypt.

Moallem, U., G. Altmark, H. Lehrer and A. Arieli, 2010. Performance of high-yielding dairy cows supplemented with fat or concentrate under hot and humid climates. J. Dairy Sci.; 93:3192-3202.

Moorby, J.M., R.J. Dewhurst, R.T. Evans and W.J. Fisher, 2002. Effects of level of concentrate feeding during the second gestation of Holstein-Friesian dairy cows. 2. Nitrogen balance and plasma metabolites. J. Dairy Sci.; 85: 178.

Morsy, A.S., 2008. Reproduction and production performance of ewes fed diet supplemented with calcium soaps of fatty acids. M.Sc. Thesis, Faculty of Agriculture, Alexandria University, Egypt.

NRC, 2001. Nutrient Requirements of Dairy Cattle, seventh ed. National Academy of Science, Washington DC.
Omer, F.M.A., 1999. Using protected fat prepared from soap industry by-products in finishing rations of Friesian bulls. Ph.D. Thesis, Faculty of Agriculture, Cairo University, Giza, Egypt.

Petit, H.V., C. Germiquet and D. Lebel, 2004. Effect of feeding whole, unprocessed sunflower seeds and flaxseed on milk production, milk composition and prostaglandin secretion in dairy cows. J. Dairy Sci.; 87: 3889.

Purushothaman, S., A. Kumar and D.P. Tiwari, 2008. Effect of feeding calcium salts of palm oil fatty acids on performance of lactating crossbred cows. Asian-Aust. J. Anim. Sci.; 21: 376 - 385.

Raafat, N.A. and M.S. Saleh, 1962. Two formulas for the conversion of cow's and buffalo's milk of different fat percentages into milk of standard fat percentage, proceeding of the $1^{\text {st }}$ Anim. Prod. Conference at Minia: 203.

Rajora, V.S., S.P. Pachauri and G.C. Gupta, 1997. Blood profiles in dairy animals of different locations and productivity. Indian J. Dairy Sci.; 50: 388.

SAS., 1990. SAS user's guide: Statistics, Version $5^{\text {th }}$ Ed. SAS Institute, INC., Cary, NC., USA.

Schalm, O.W., 1965. "Veterinary Hematology" $2^{\text {nd }}$ Ed. Lea and Febiger. Philadelphia, USA.

Sklan, D., M. Kaim, U. Moallem and Y. Folman, 1994. Effects of dietary calcium soaps on milk yield, body weight, reproductive hormones and fertility in first parity and older cows. J. Dairy Sci.; 77:1652.

Soliman, E.B., A.K.I. Abd El-Moty, S.T.M. Fahmy and E.M.I. Nour-El-Dein, 2001. Some physiological responses of lactating Friesian cows to dietary fat supplementation. Alex. J. Agric. Res.; 46: 21-29.

Titi, H., 2011. Effects of varying levels of protected fat on performance of Shami goats during early and mid lactation. Turk. J. Vet. Anim. Sci.; 35:67-74.

Vandeharr, J.J.M., 2005. Dairy cattle in: Basic animal nutrition and feeding, $5^{\text {th }}$ Ed. John Wiley and Son, Inc. USA.

Wang J.P., D.P. Bu, J.Q. Wang, X.K. Huo, T.J. Guo, H.Y. Wei, L.Y. Zhou, R.R Rastani, L.H. Baumgard, F.D. Li, 2010. Effect of saturated fatty acid supplementation on production and metabolism indices in heat-stressed midlactation dairy cows. J Dairy Sci.; 93:41214127.

Zhang, H., Z. Wang, G. Liu, J. He and C.H. $\mathrm{Su}$, 2011. Effect of dietary fat 
supplementation on milk components and

blood parameters of early-lactating cows

under heat stress. Slovak J. Anim. Sci.; 44: $52-58$.

Table 1. Effect of protected fat supplementation on some productive performances of lactating Egyptian buffaloes (mean \pm S.E.)

\begin{tabular}{|c|c|c|c|c|c|}
\hline \multirow[t]{2}{*}{ Items } & \multicolumn{3}{|c|}{ Treatments } & \multirow{2}{*}{$\begin{array}{l}\text { Mean } \\
\text { S.E. }\end{array}$} & \multirow[t]{2}{*}{ Sig. } \\
\hline & $\mathrm{T} 1$ & $\mathrm{~T} 2$ & T3 & & \\
\hline Milk yield $(\mathrm{kg} / \mathrm{h} / \mathrm{d})$ & $8.25^{\mathrm{c}}$ & $9.81^{b}$ & $11.20^{\mathrm{a}}$ & 0.242 & * \\
\hline $7 \% \mathrm{FCM}(\mathrm{kg} / \mathrm{h} / \mathrm{d})$ & $8.38^{c}$ & $10.54^{\mathrm{b}}$ & $12.80^{\mathrm{a}}$ & 0.278 & $*$ \\
\hline Fat yield $(\mathrm{kg} / \mathrm{d})$ & $0.590^{\mathrm{c}}$ & $0.756^{\mathrm{b}}$ & $0.936^{\mathrm{a}}$ & 0.001 & $*$ \\
\hline TDMI $(\mathrm{kg} / \mathrm{h} / \mathrm{d})$ & $16.67^{\mathrm{c}}$ & $17.97^{\mathrm{b}}$ & $19.64^{\mathrm{a}}$ & 1.273 & $*$ \\
\hline FCM/TDMI & $0.50^{\mathrm{c}}$ & $0.59^{\mathrm{b}}$ & $0.65^{\mathrm{a}}$ & 0.005 & $*$ \\
\hline
\end{tabular}

Table 2. Effect of protected fat supplementation on rectal temperature and respiration rate of lactating Egyptian buffaloes (mean \pm S.E.)

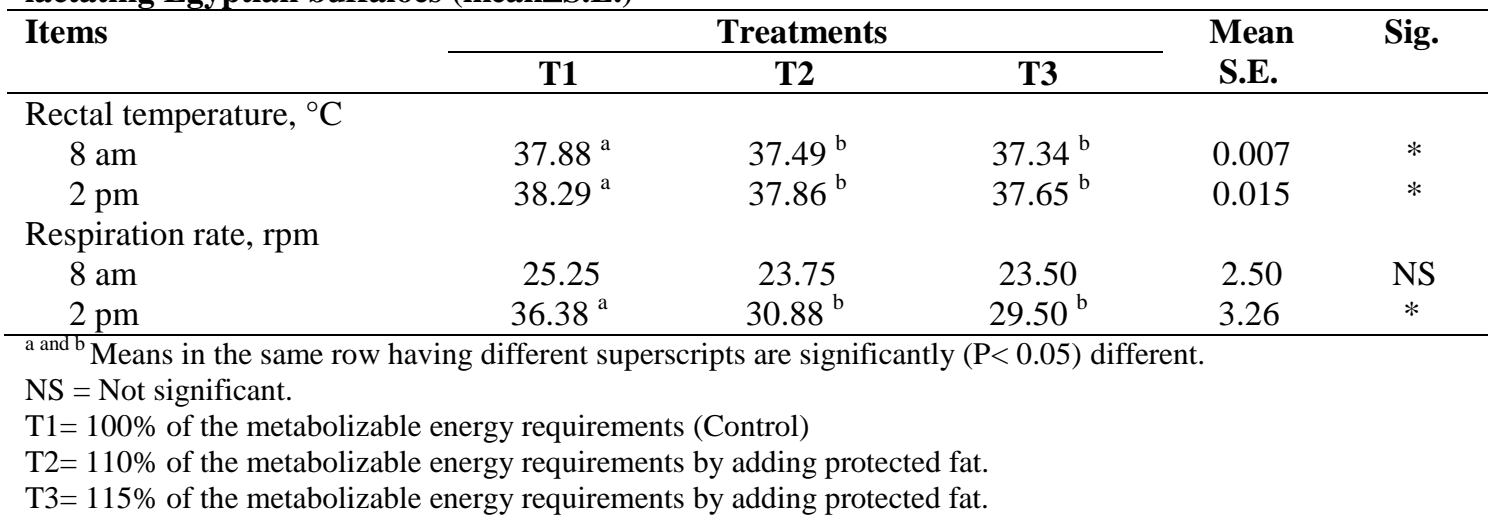

Table 3. Effect of protected fat supplementation on blood hematological parameters of lactating Egyptian buffaloes (mean \pm S.E.)

\begin{tabular}{lccccc}
\hline Items & \multicolumn{3}{c}{ Treatments } & Mean & Sig. \\
\cline { 2 - 4 } & T1 & T2 & T3 & S.E. & \\
\hline Hb $(\mathrm{g} / \mathrm{dl})$ & $13.0^{\mathrm{b}}$ & $14.69^{\mathrm{a}}$ & $15.93^{\mathrm{a}}$ & 0.351 & $*$ \\
PCV $(\%)$ & $31.5^{\mathrm{b}}$ & $35.5^{\mathrm{a}}$ & $38.0^{\mathrm{a}}$ & 1.944 & $*$ \\
RBC's $\left(\times 10^{6} / \mathrm{mm}^{3}\right)$ & $6.93^{\mathrm{b}}$ & $7.30^{\mathrm{ab}}$ & $7.62^{\mathrm{a}}$ & 0.052 & $*$ \\
WBC's $\left(\times 10^{3} / \mathrm{mm}^{3}\right)$ & $8.39^{\mathrm{b}}$ & $8.67^{\mathrm{ab}}$ & $8.91^{\mathrm{a}}$ & 0.017 & $*$ \\
MCH $(\mu \mu \mathrm{g})$ & $18.78^{\mathrm{b}}$ & $20.14^{\mathrm{a}}$ & $20.41^{\mathrm{a}}$ & 0.436 & $*$ \\
MCV $(\mathrm{Cu} . \mu)$ & $45.49^{\mathrm{b}}$ & $48.52^{\mathrm{ab}}$ & $49.90^{\mathrm{a}}$ & 2.929 & $*$ \\
MCHC $(\%)$ & 41.29 & 41.50 & 41.92 & 0.858 & NS \\
\hline
\end{tabular}

${ }^{\mathrm{a} a n d} \mathrm{~b}$ Means in the same row having different superscripts are significantly $(\mathrm{P}<0.05)$ different.

NS $=$ Not significant.

$\mathrm{T} 1=100 \%$ of the metabolizable energy requirements (Control).

$\mathrm{T} 2=110 \%$ of the metabolizable energy requirements by adding protected fat.

$\mathrm{T} 3=115 \%$ of the metabolizable energy requirements by adding protected fat.

The values of MCH, MCV and MCHC were calculated according to Schalm (1965). 
Table 4. Effect of protected fat supplementation on plasma metabolites, thyroid hormones and prolactin of lactating Egyptian buffaloes (mean \pm S.E.)

\begin{tabular}{lccccc}
\hline & \multicolumn{3}{c}{ Treatments } & Mean & Sig. \\
\cline { 2 - 5 } Plasma constituents & T1 & T2 & T3 & S.E. & \\
\hline Glucose (mg/dl) & $59.5^{\mathrm{c}}$ & $69.0^{\mathrm{b}}$ & $75.0^{\mathrm{a}}$ & 0.500 & $*$ \\
Total protein (g/dl) & $7.08^{\mathrm{b}}$ & $7.43^{\mathrm{a}}$ & $7.72^{\mathrm{a}}$ & 0.019 & $*$ \\
Albumin (g/dl) & $3.80^{\mathrm{b}}$ & $4.10^{\mathrm{a}}$ & $4.13^{\mathrm{a}}$ & 0.011 & $*$ \\
Globulin (g/dl) & $3.28^{\mathrm{b}}$ & $3.33^{\mathrm{b}}$ & $3.59^{\mathrm{a}}$ & 0.004 & $*$ \\
A/G ratio & $1.16^{\mathrm{b}}$ & 1.23 & $1.15^{\mathrm{a}}$ & 0.001 & $\mathrm{NS}$ \\
Total lipid (mg/dl) & $422.5^{\mathrm{c}}$ & $497.5^{\mathrm{b}}$ & $545.0^{\mathrm{a}}$ & 0.481 & $*$ \\
Cholesterol (mg/dl) & $67.0^{\mathrm{c}}$ & $78.5^{\mathrm{b}}$ & $94.0^{\mathrm{a}}$ & 0.543 & $*$ \\
Triglycerides (mg/dl) & $25.25^{\mathrm{c}}$ & $36.00^{\mathrm{b}}$ & $44.75^{\mathrm{a}}$ & 1.167 & $*$ \\
Triiodothyronine (ng/ml) & $1.21^{\mathrm{b}}$ & $1.28^{\mathrm{b}}$ & $1.46^{\mathrm{a}}$ & 0.002 & $*$ \\
Thyroxin (ng/ml) & $41.68^{\mathrm{c}}$ & $52.78^{\mathrm{b}}$ & $61.62^{\mathrm{a}}$ & 0.023 & $*$ \\
Thyroxin/triiodothyronine ratio & $34.45^{\mathrm{b}}$ & $41.23^{\mathrm{a}}$ & $42.21^{\mathrm{a}}$ & 1.460 & $*$ \\
\hline
\end{tabular}

$\mathrm{A}, \mathrm{b}$ and $\mathrm{c}$ Means in the same row having different superscripts are significantly $(\mathrm{P}<0.05)$ different.

NS $=$ Not significant.

$\mathrm{T} 1=100 \%$ of the metabolizable energy requirements (Control).

$\mathrm{T} 2=110 \%$ of the metabolizable energy requirements by adding protected fat.

$\mathrm{T} 3=115 \%$ of the metabolizable energy requirements by adding protected fat.

بعض الإستجابات الإنتاجية والفسيولوجية للجاموس المصرى الحلاب نتيجة التغذية على علائق مزودة بالدهن المحمى الاست

عبد المعطى خيرى ابراهيم ، عصام بسيونى سليمان ، سمير توفيق محمد ، عماد الاين محمد ابراهيم قسم الإنتاج الحيوانى، كلية الزراعة، جامعة المنيا

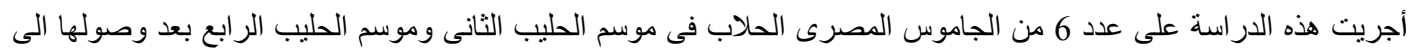

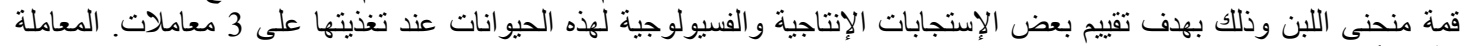

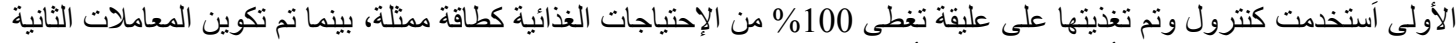

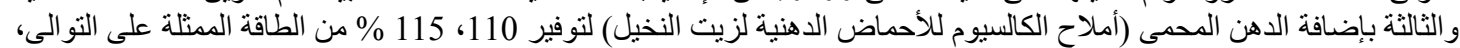

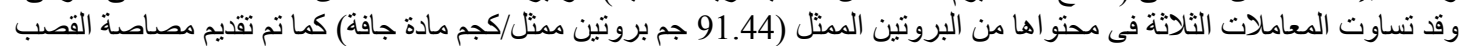

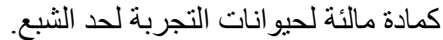

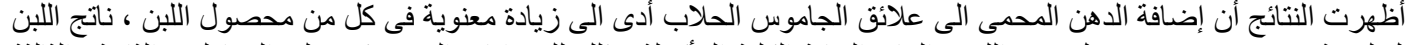

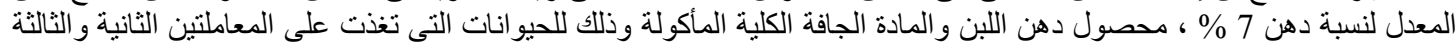

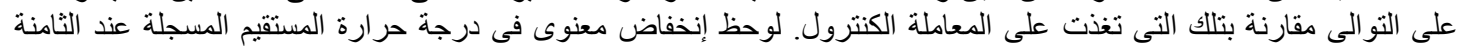

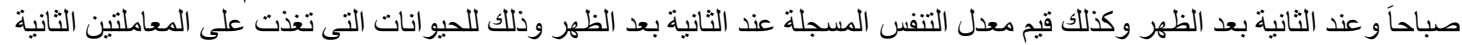

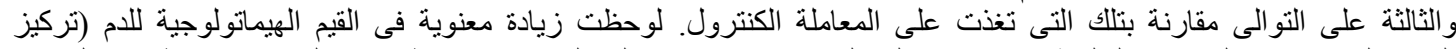

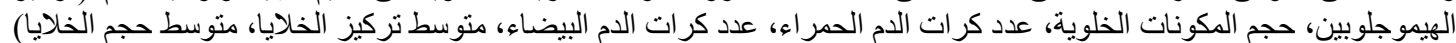

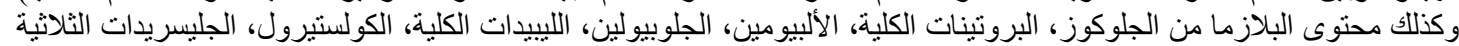

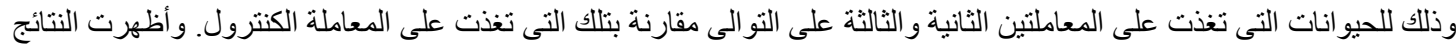

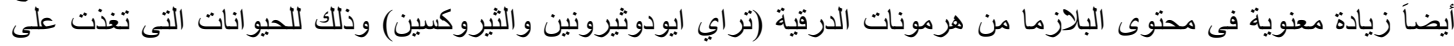

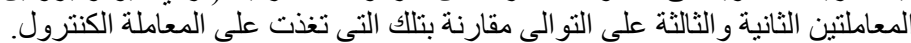

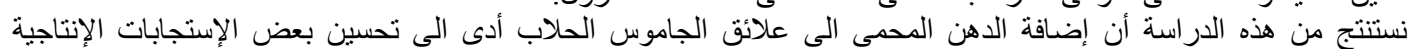
و الفسيولوجية لهذه الحيو انات و هذا يرجع الى رفع كفاءة الأنثطة الحيوية لها. 